\title{
症例報告：
}

\section{A Case of Digitalis Intoxication Brought about by Eating Digitalis Leaves by Mistake}

\author{
Bunji KAKU*, Yutaka IGARASHI*, Tatsushi MORITA*, \\ Hideo KOSHIDA*, Isao TANAKA*, Tomio KAMETANI*, \\ Takeyuki HORIGAMI*, Tadayuki NAGAI* and Masayoshi KATO*
}

\begin{abstract}
An 78-year-old woman visited our hospital with the chief complaints of abdominal pain, nausea, vomiting and diarrhea. She was operated on for gastric ulcer when she was 56 years old and complained of abdominal discomfort after operation. One day she wished to take Confrey (Symphytum officinale), but she took digitalis leaves (Digitalis purpurea) by mistake. On admission she was drowsy and the systolic blood pressure was $60 \mathrm{mmHg}$ on palpation. Electrocardiograms showed bradycardia, irregular $\mathrm{AV}$-nodal rhythm and ST depressions and T wave inversions with the shortening of the QT interval. Serum levels were potassium, $6.4 \mathrm{mEq} / 1$; BUN, $34.4 \mathrm{mg} / \mathrm{dl}$; creatinine, $1.5 \mathrm{mg} / \mathrm{dl}$; digoxin, $2.0 \mathrm{ng} / \mathrm{ml}$ (therapeutic level, up to $2.0 \mathrm{ng} / \mathrm{ml}$ ) ; and digitoxin, $111 \mathrm{ng} / \mathrm{ml}$ (therapeutic level, up to $25 \mathrm{ng} / \mathrm{ml}$ ). Hemodynamic data showed HR, 49 beats $/ \mathrm{min}$; CO, $2.81 / \mathrm{min} ; \mathrm{CI}, 2.31 \mathrm{l} / \mathrm{min} / \mathrm{m}^{2} ; \mathrm{SV}, 57 \mathrm{ml} /$ beat and SI, $47 \mathrm{ml} / \mathrm{beat} / \mathrm{m}^{2}$ on administration of dopamine $7 \mu \mathrm{g} / \mathrm{kg} / \mathrm{min}$. So VVI pacing was started at $70 \mathrm{bpm}$ and $\mathrm{CO}$ increased to $3.6 \mathrm{l} / \mathrm{min}$ after pacing. But unfortunately she died of ventricular fibrillation. The digitalis leaves resemble the Confrey leaves and it is easy to mix up these two plants. Although this is a rare case, digitalis intoxication can be life-threatening. So we should prepared ourselves for the treatment of patients poisoned with digitalis and other poisonous herbs.
\end{abstract}

(1) Digitalis purpurea (2) Confrey (3) digitalis intoxication (4) ventricular fibrillation

\section{INTRODUCTION}

In 1785 , after using the medicinal herb for ten years, William Withering introduced Digitalis purpurea in An Account of the Foxglove ${ }^{1}$. Since then we have gained enormous sophistication in administering digitalis glycosides. In recent years we have come to use manufactured digitalis glycosides as a drug and digitalis leaves are not directly used as a drug. Digitalis purpurea is mainly grown as an ornamental plant in Japan.

Confrey (Symphytum officinale) is grown as a medicinal herb and often eaten in the agricultural district. These two plants' leaves resemble and the patient in our case, an 78-year-old woman, ate digitalis leaves by mistake. She visited our hospital with digitalis intoxication and serum levels were digoxin, $2.0 \mathrm{ng} / \mathrm{ml}$ (therapeutic level, up to $2.0 \mathrm{ng} /$ $\mathrm{ml})$; and digitoxin, $111 \mathrm{ng} / \mathrm{ml}$ (therapeutic level, up to $25 \mathrm{ng} / \mathrm{ml}$ ). Unfortunately she died of ventricular fibrillation. Although this is a rare case, misuse of these plants is sometimes fatal. So, we must be careful not to misuse these plants.

\section{CASE}

The patient, an 78-year-old woman, first visited

\footnotetext{
*Department of Internal Medicine, Kouseiren Takaoka Hospital, Takaoka, Toyama （受付1993年 8 月 9 日）
} 

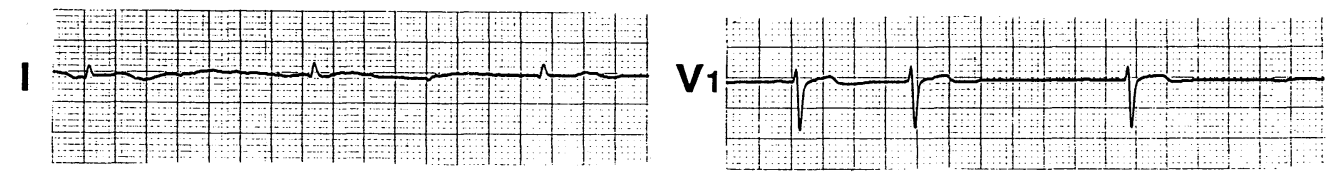

II

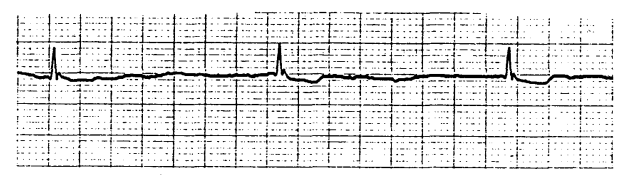

III
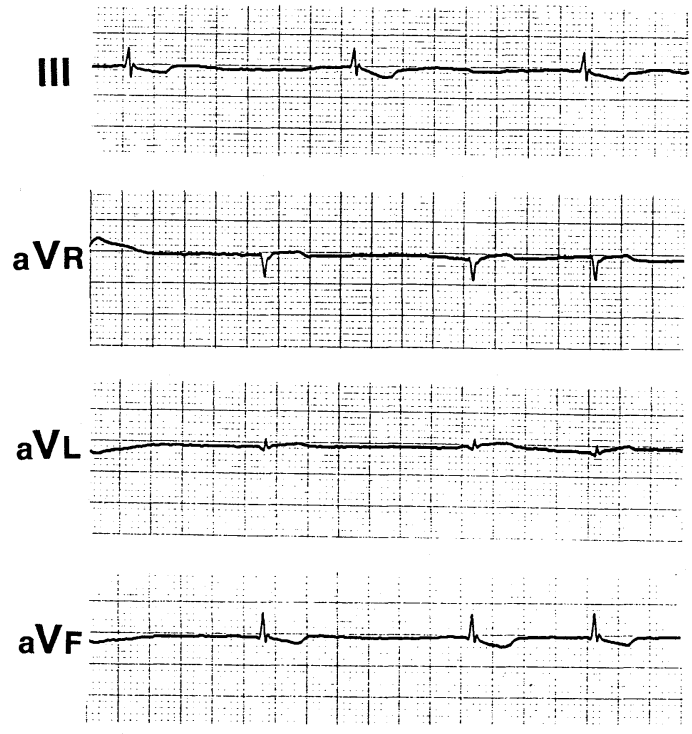
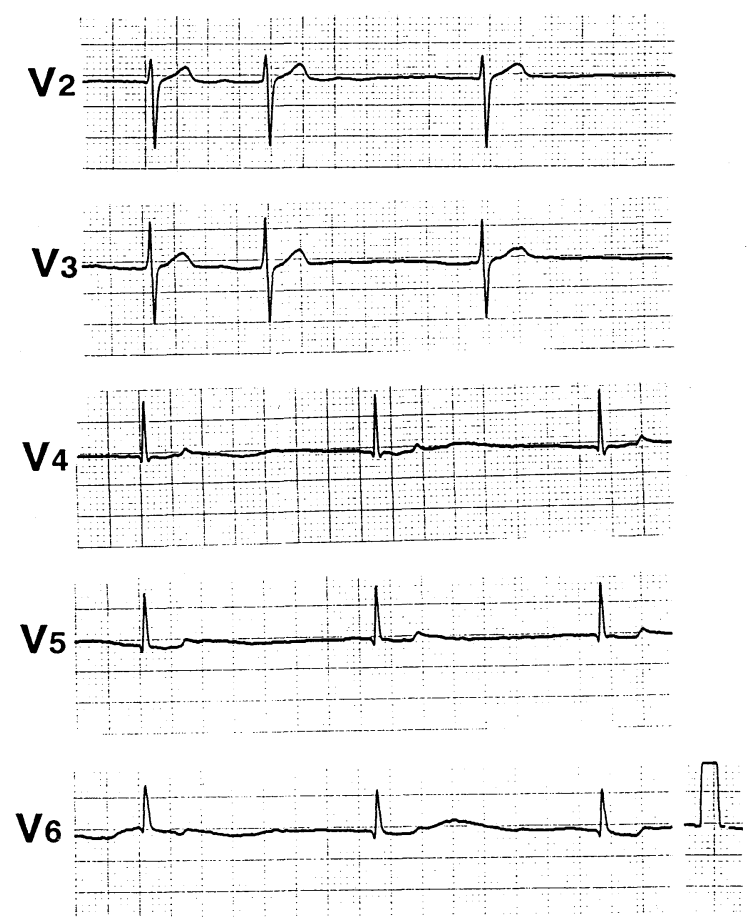

Fig. 1. Electrocardiograms showed bradycardia, irregular AV-nodal rhythm, ST depressions and $\mathrm{T}$ wave inversions with shortening of the QT interval

our hospital with the chief complaints of abdominal pain, nausea, vomiting, and diarrhea. There was no particular family history. She was operated on for gastric ulcer at the age of 56 and complained of abdominal discomfort since then. One day, on televsion she learned that Confrey might be efficacious against abdominal discomfort. She picked three leaves of the foxglove in a neighbor's garden, fried and ate them, believing that they are Confrey leaves. They tasted very bitter. Two hours after eating them, she began to complaint nausea and abdominal pain, 4 hours after, vomiting and diarrhea appeared and 19 hours after, she was brought into our hospital in an ambulance. She was a small old person ; her height, $145 \mathrm{~cm}$, her weight, $35 \mathrm{~kg}$. On admission she was drowsy and the systolic blood pressure was $60 \mathrm{mmHg}$ on palpation. Her face was very pale. Chest X-ray photographs showed mild cardiomegary. Electrocardiograms showed bradycardia, irregrular AV-nodal rhythm, ST depressions and $\mathrm{T}$ wave inversions with the shortening of the QT interval (Fig. 1). Serum levels were potassium, $6.4 \mathrm{mEq} / 1$; BUN, $34.3 \mathrm{mg} / \mathrm{dl}$ and creatinine, $1.5 \mathrm{mg} / \mathrm{dl}$ (Table 1). Hemodynamic data showed HR, 49 beats/min ; CO (cardiac output), 2.8 $1 / \mathrm{min} ; \mathrm{CI}$ (cardiac index), $2.31 \mathrm{l} / \mathrm{min} / \mathrm{m}^{2} ; \mathrm{SV}$ (stroke volume), $57 \mathrm{ml} /$ beat; SI (stroke index), $47 \mathrm{ml} /$ beat/ $\mathrm{m}^{2}$ RVEDP (right ventricular end diastolic pressure), $11 \mathrm{mmHg}$; mean RA (right atrial pressure), 11 $\mathrm{mmHg}$ and $\mathrm{AO}$ (aortic blood pressure), $80 / 40 \mathrm{mmHg}$ on administration of dopamine $7 \mu \mathrm{g} / \mathrm{kg} / \mathrm{min}$. So VVI pacing was started at $70 \mathrm{bpm}$ and $\mathrm{CO}$ increased to 3 . $6 \mathrm{l} / \mathrm{min}$, AO increased to $120 / 60 \mathrm{mmHg}$ and RVEDP, mean RA decreased after pacing (Table 2). Fig. 2 shows the clinical course of this case. At the beginning, we could not understand digitalis intoxication 
Table 1.

\begin{tabular}{|c|c|c|c|}
\hline $\mathrm{RBC}$ & $356 \times 10^{4} / \mathrm{mm}^{3}$ & GOT & $44 \mathrm{IU} / 1$ \\
\hline WBC & $9600 / \mathrm{mm}^{3}$ & GPT & $33 \mathrm{IU} / 1$ \\
\hline $\mathrm{Hb}$ & $12.1 \mathrm{~g} / \mathrm{dl}$ & LDH & $411 \mathrm{IU} / 1$ \\
\hline $\mathrm{Ht}$ & $34.9 \%$ & ALP & $224 \mathrm{IU} / 1$ \\
\hline PL & $12.6 \times 10^{4} / \mathrm{mm}^{3}$ & $\gamma$-GTP & $20 \mathrm{IU} / 1$ \\
\hline $\mathrm{Na}$ & $134 \mathrm{mEq} / 1$ & Ch-E & $0.58 \Delta \mathrm{PH}$ \\
\hline K & $6.4 \mathrm{mEq} / 1$ & CPK & $36 \mathrm{IU} / 1$ \\
\hline $\mathrm{Cl}$ & $105 \mathrm{mEq} / \mathrm{l}$ & TP & $6.7 \mathrm{~g} / \mathrm{dl}$ \\
\hline $\mathrm{Ca}$ & $9.5 \mathrm{mg} / \mathrm{dl}$ & Alb & $65.5 \%$ \\
\hline $\mathrm{P}$ & $5.5 \mathrm{mg} / \mathrm{dl}$ & $\alpha 1$ & $2.5 \%$ \\
\hline BUN & $34.4 \mathrm{mg} / \mathrm{dl}$ & $\alpha 2$ & $9.2 \%$ \\
\hline $\mathrm{Cr}$ & $1.5 \mathrm{mg} / \mathrm{dl}$ & $\beta$ & $8.0 \%$ \\
\hline UA & $7.4 \mathrm{mg} / \mathrm{dl}$ & $\gamma$ & $14.8 \%$ \\
\hline pH & 7.38 & & \\
\hline $\mathrm{PCO}_{2}$ & $41.2 \mathrm{mmHg}$ & & \\
\hline $\mathrm{PO}_{2}$ & $86.6 \mathrm{mmHg}$ & & \\
\hline $\mathrm{HCO}_{3}^{-}$ & $24.2 \mathrm{mEq} / 1$ & & \\
\hline $\mathrm{BE}$ & $-0.3 \mathrm{mEq} / 1$ & & \\
\hline $\mathrm{O}_{2} \mathrm{SAT}$ & $96.4 \%$ & & \\
\hline
\end{tabular}

Table 2. Hemodynamic data

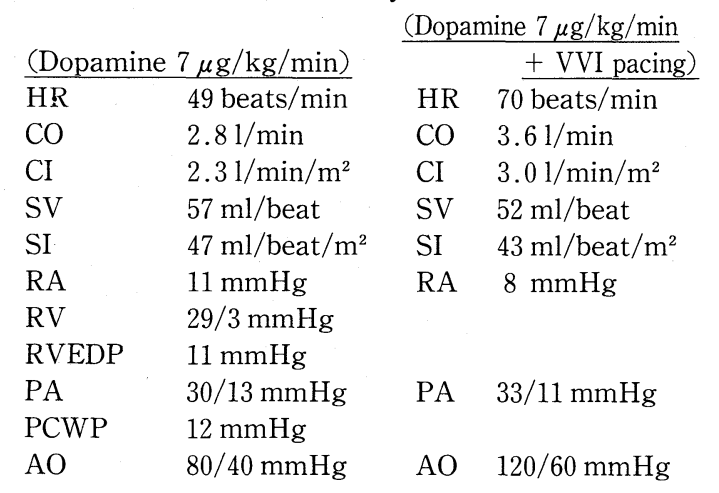

completely because it was our first experience in seeing digitalis leaves. But from its chief complaints and ECG change, we guessed that the plant she ate caused similar poisoning effects to those of the foxglove. Serum levels were digoxin, $2.0 \mathrm{ng} / \mathrm{ml}$ (therapeutic level, up to $2.0 \mathrm{ng} / \mathrm{ml}$ ) ; and digitoxin, $111 \mathrm{ng} / \mathrm{ml}$ (therapeutic level, up to $25 \mathrm{ng} / \mathrm{ml}$ ). But it took two days to determine the serum digitoxin level because in our hospital's laboratory, we could not measure its serum level and we had to ask an outside laboratory to do so. What was worse, she developed acute renal failure perhaps because of low cardiac output. Although cardiac output increased after VVI pacing, one hour urine volume was still low.

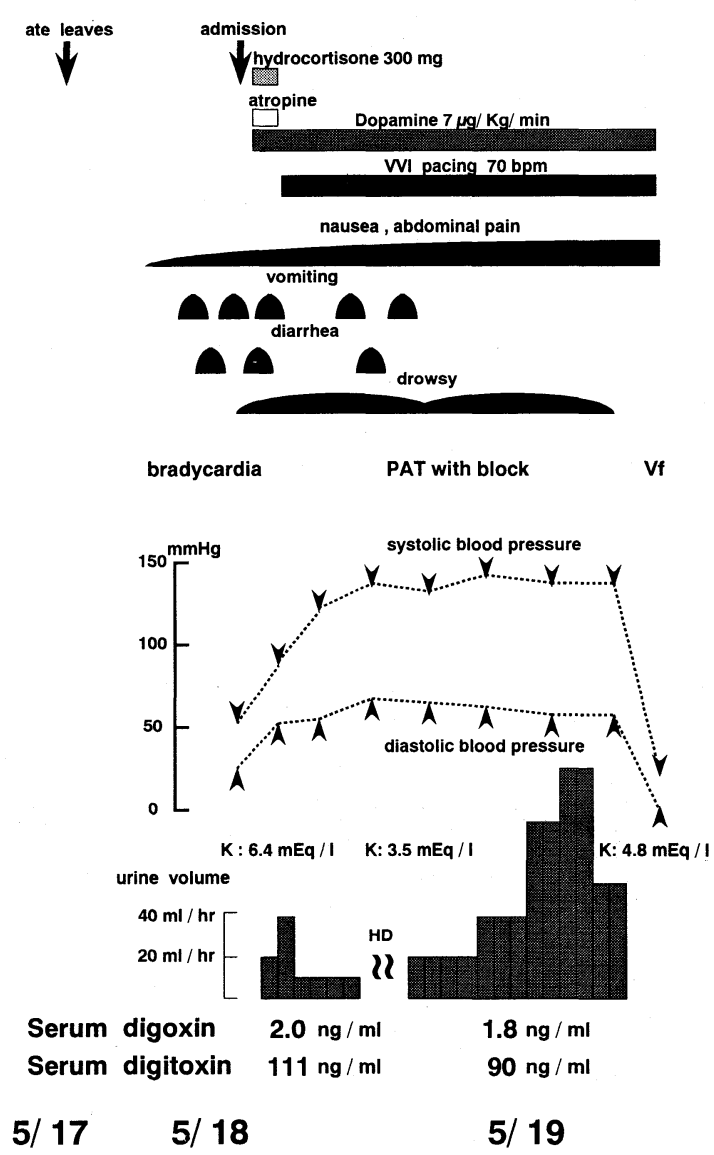

Fig. 2. The clinical course of this case.

Because the urine volume did not respond to diuretics and we were afraid of increased accumulation of serum potassium, hemodialysis was done. After hemodialysis serum potassium level decreased to $3.5 \mathrm{mEq} / 1$ and fortunately the frequency of ventricular premature beats did not increase at this time $^{2 \sim 4)}$. After that her complaints continued. One day after admission, it suddenly showed ventricular fibrillation on monitor ECG and cardiopulmonary resuscitation was done at once. Intravenous administration of lidocine and cardioversion was not effective and unfortunately she died of ventricular fibrillation. Fig. 3 shows the course of her electrocardiographic changes. It shows the ECG before digitalis intoxication (a), it shows the ECG at admission (b), it shows the ECG after VVI pacing (c) and it shows the ECG of ventricular fibrillation (d). 
(a)

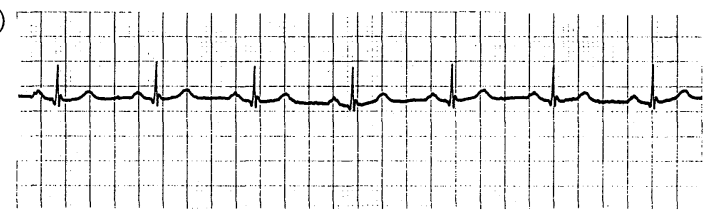

(b)

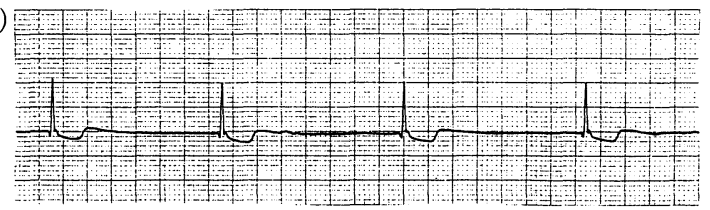

(c)

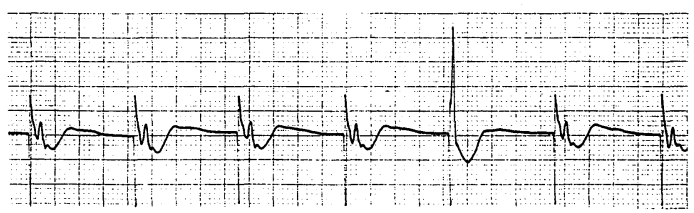

(d)

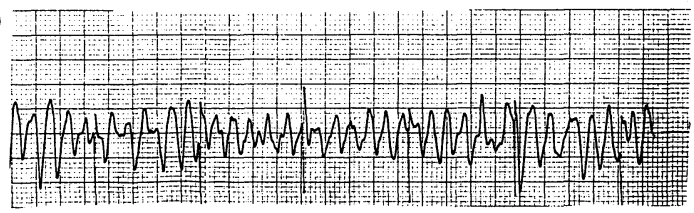

Fig. 3. The course of her electrocardiographic changes. (a) The ECG before digitalis intoxication. (b) The ECG at admission. (c) The ECG after VVI pacing. (d) The ECG of ventricular fibrillation.

\section{DISCUSSION}

Digitalis purpurea is known as the foxglove and it contains digitoxin, digoxin and digitalin etc. ${ }^{5}$. But its principal element is digitoxin. Although Digitalis purpurea's habitat is originally Europe, it was introduced into Japan in the Edo period. Because it puts forth pretty flowers, we grow it as an ornamental plant in Japan and do not use its leaves in medicine. On the other hand, Confrey (Symphytum officinale) is grown as a medicinal herb, but its effect is really doubtful, and often eaten particularly in the agricultural district. These two plants' leaves are exactly alike and it is hard to distinguish between these two plants. In our case, although the patient wished to eat Confrey, she ate Digitalis purpurea by mistake. Fig. 4 shows Digitalis purpurea and Confrey in a neighbor's garden. Fig. 5 shows the discriminating points of these two plants's leaves. (1) Although in the leaf of Digitalis purpurea, the blade lasts to the stem, in the leaf of Confrey, the blade ends before the stem. (2) Although the leaf of Digitalis purpurea has saw-like edges, the leaf of Confrey has smooth edges. (3) Digitalis purpurea tastes very bitter. Digitalis purpurea's principal element is digitoxin. Digitoxin is absorbed from intestinal lumen rapidly and is $97 \%$ protein-bound and has a mean serum half-life of 146 hours $^{5,6)}$. In this case, the dry weight of three sheets of digitalis leaf is $2.4 \mathrm{~g}$ and the fetal dose of digitalis leaves is generally $2 \sim 3 \mathrm{~g}^{5,7}$. What was worse, the patient was a small old person; her age, 78 , her height, 145 $\mathrm{cm}$, her weight, $35 \mathrm{~kg}$. It was assumed that digitalis intoxication must have been too much on her considering her physical condition. The methods of medical treatment of digitalis intoxication are that ; 1. For purposes of impeding absorption washing out the patient's stomach within 8 hours and administration of sickening drugs or laxatives are done. 2. For purposes of impeding the enterohepatic circulation of digitoxin activated charcoal or cholestyramine is administered $^{8 \sim 10)}$. 3. For purposes of removing digitoxin plasmapheresis is done and the clearance of digitoxin by plasmapheresis is much larger than that by hemodialysis ${ }^{11}$. 4 . For purposes of preventing bradycardia cardiac pacing or intravenous injection of atropine is done. 5. For purposes of preventing ventricular arrhythmia correction of serum potassium, intravenous injection of lidocaine or phenytoin are done. 6 . Direct-current countershock is used when all other methods have failed in the face of a life-threatening rhythm disturbance. 7 . Digoxin-specific antibody is still not used in Japan generally. This time, the patient unfortunately died. Reflecting on the case, we would like to mention the following points: (1) This was a rare case and we could not understand digitalis intoxication completely at first beceuse it was our first experience in seeing digitalis leaves. It took about one day to understand digitalis intoxication completely. (2) In this case, perhaps acute renal failure resulted from digitalis intoxication and we were afraid of in- 


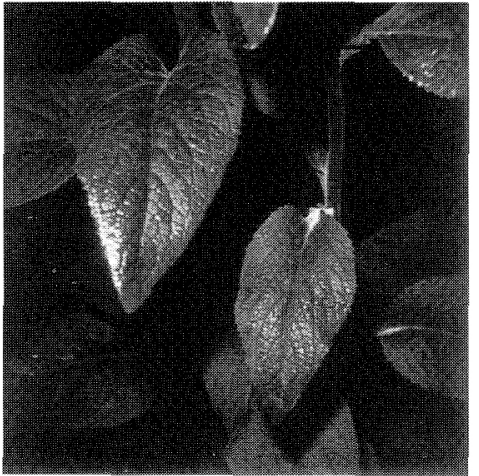

Digitalis purpurea

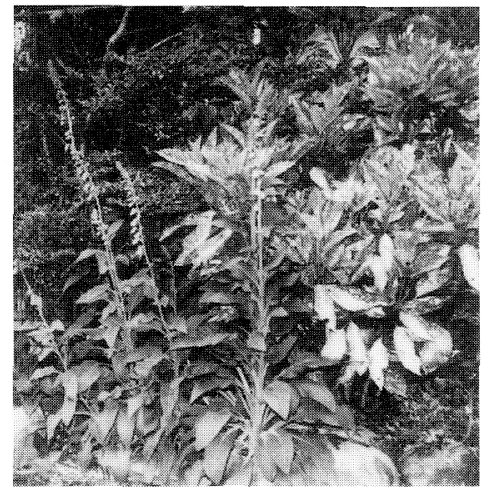

Digitalis purpurea

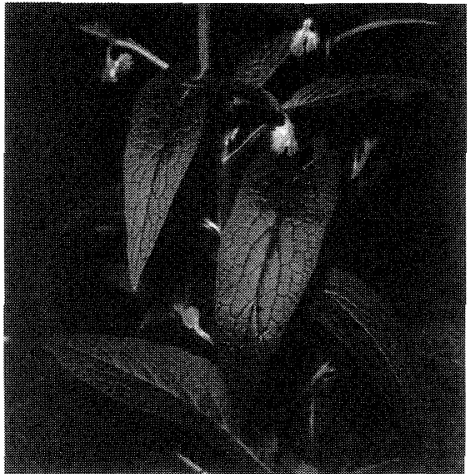

Confrey

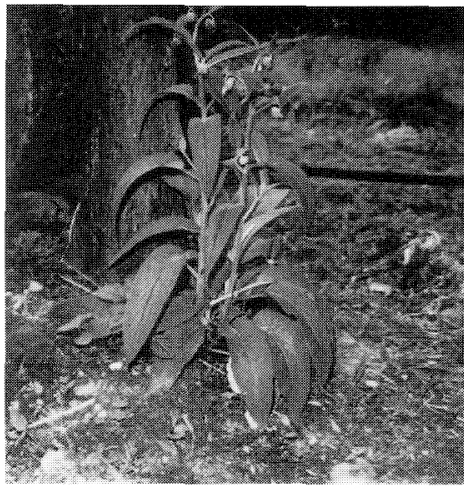

Confrey

Fig. 4. Digitalis purpurea and Comfrey in a neighbor's garden.

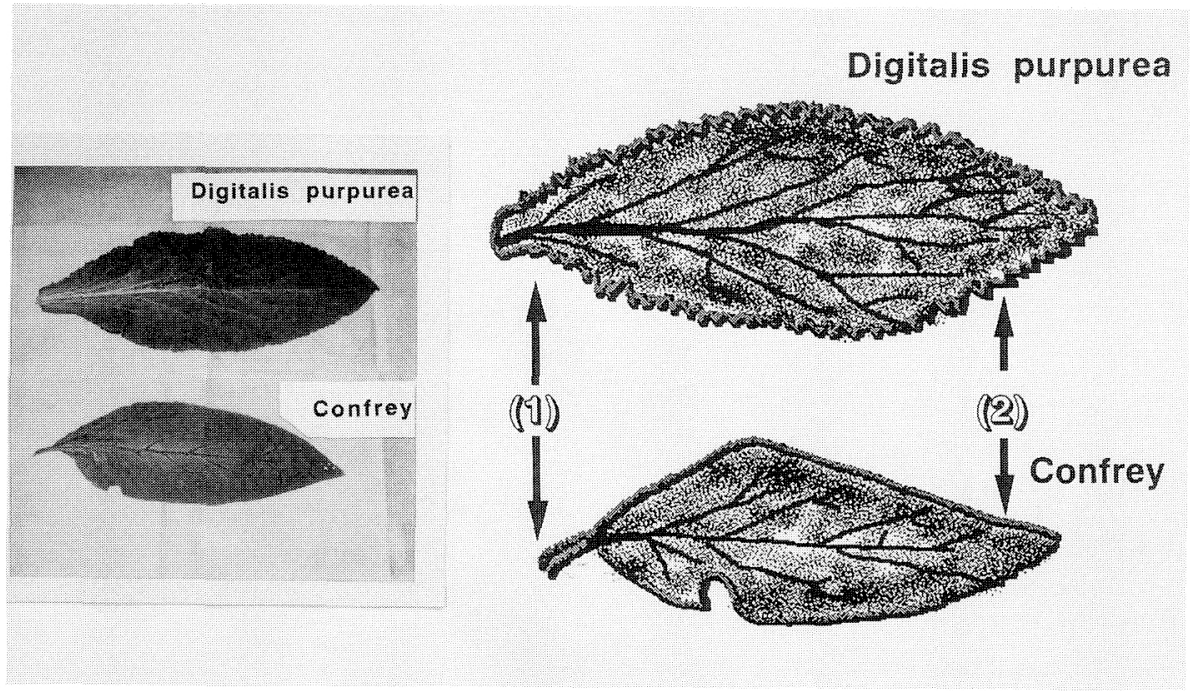

Fig. 5. The distinguishing points of these two plants's leaves.

(1) Although in the leaf of Digitalis purpurea, the blade lasts to the stem, in the leaf of Confrey, the blade ends before the stem.

(2) Although the leaf of Digitalis purpurea has saw-like edges, the leaf of Confrey has smooth edges 
creased accumulation of serum potassium, so hemodialysis was done. Because the protein-binding rate of digitoxin was high, the clearance of digitoxin by hemodialysis was little. So plasmapheresis should have been done. (3) It took two days to determine the serum digitoxin level because in our hospital's laboratory, we could not measure its serum level and we had to depend on an outside laboratory for measurement. This time we experienced a cese of digitalis intoxication brought about by eating digitalis leaves by mistake. Although this is a rare case, digitalis intoxication can be lifethreatening. So we should be prepared for giving similar patients prompt and effective attention.

\section{REFERENCES}

1) Withering $W:$ An account of the foxglove, and some of its medical uses: With practical remarks on dropsy and other diseases. Med Classics 2: 259-443, 1937

2) A. Blumberg: Cardiac Arrhythmias in Patients on Maintenance Hemodialysis. Nephron 33: 91-95, 1983

3 ) Gail Morrison: Mecanism and prevention of cardiac arrhythmias in chronic hemodialysis patients. Kidney
International $7: 811-819,1980$

4) Glenn D. Lubash, M. D. : Electrocardiographic Changes during Hemodialysis with the Artifical Kidney: The Treatment of Digitalis Intoxication. Circulation 19: 552 $-556,1959$

5 ) Peter Cooper, F. P. S. : Poisoning by drugs and chemicals, plants and animals. Ishiyaku publishers, Inc. Bunkyou, Tokyo, Japan 1989, 262-265

6) Lukas DS. : Some aspects of the distribution and disposition of digitoxin in man. Ny Acad Sci 179 : 338-361, 1971

7) Robert H. Dreisbach, M. D. phD : Handbook of Poisoning: Diagnosis, Treatment. Hirokawa Publishig Co. Hongo, Tokyo, Japan 1977, 413-415

8) Doherty, J. E., de Sayza, N., Kane J. J., et al : Clinical pharmacokinetics of digitalis glycosides. Prog. Cardiovasc. Dis. $21: 141-158,1978$

9) Gaetano Bazzano, M. D., phD: Digitalis intoxication: Treatment With a New Steroid-Binding Resin. JAMA 8 : $828-830$

10) S. Pond, M. Jacobs, J. Marks et al : Treatment of digitoxin overdose with oral activated charcoal. The Lancet 21 : 1177, 1981

11) Peter, U., Risler, T., Granbensee, B.: Digitoxin elimination by plasma separation. in Plasma Exchange (ed. by H. G. Siberth), Schattauer, Stuttgart-New York 1980, 365

\section{ジギタリス葉を誤って食し，ジギタリス中毒となった 1 例 郭 文治*, 五十嵐豊*, 森田達史 ${ }^{*}$, 越田英夫*, 田中 功*, 亀谷富夫*, 堀上健幸*, 永井忠之*, 加藤正義*}

症例は78歳女性。テレビにてコンフリーという薬草を食すと胃腸の具合が良くなると聞き，隣人 宅に生えていた自生ジギタリスをコンフリーと誤って食した。食後 4 時間頃より吐気, 腹痛出現, その後嘔吐，下痢も出現した。翌日になっても上記症状は消失せず，意識レベルも低下してきたの で当院受診した。入院時患者は顔面蒼白で苦悶様，血圧触診で $60 \mathrm{mmHg}$ 台，著明な徐脈を呈し，低 心拍出量が起因すると思われる急性腎不全像も呈していた。血中ジゴキシン濃度は $2.0 \mathrm{ng} / \mathrm{ml}$, 血中 ジギトキシン濃度は $111 \mathrm{ng} / \mathrm{ml}$ と著明な高值を示した。患者は第 2 病日に治療のかいるなく心室細 動にて死亡した。自生ジギタリスを誤食した例は比較的診しく，本例の様に死亡するケースもあり 臨床上重要と考光られたので報告した。

*厚生連高岡病院 第 2 内科 